\title{
Pengaruh Stres Kerja Terhadap Produktivitas Kerja Pegawai Di IAIN Kendari
}

\author{
Syamsuddin $^{1}$, Kasim $^{2}$, Sulistyorini ${ }^{3}$, Abdul Kadir ${ }^{4}$, Nur Alim ${ }^{5}$ \\ ${ }^{1}$ Institut Agama Islam Negeri Kendari \\ Email: syamsuddinjufry@ gmail.com \\ ${ }^{2}$ Institut Agama Islam Negeri Kendari \\ Email: kaisarkshym@gmail.com \\ ${ }^{3}$ Institut Agama Islam Negeri Tulungagung \\ Email: Sulistyorini12@yahoo.co.id \\ ${ }^{4}$ Institut Agama Islam Negeri Kendari \\ Email: abdir_edu@yahoo.co.id \\ ${ }^{4}$ Institut Agama Islam Negeri Kendari \\ Email: nuralimbasri@gmail.com
}

\begin{abstract}
This article aims to describe and analyze the influence of occupational stress on the workmanship of employees of IAIN Kendari.This research uses a quantitative approach through causal research. The population of this research is all of IAIN Kendari employees.The total population in this study was 123 people consisting of officers and lecturers who had additional administrative tasks ranging from rectorate level to study program.Determination of the number of samples in this study using the Slovin formula. From the results of the calculation obtained a sample amount of 94 peoples. The results showed that there was a negative impact on work stress on the productivity of IAIN Kendari employees with a coefficient of determination of- 0.182 or had an influence of $18.2 \%$.This gives the meaning that working stress will negatively affect the working productivity of IAIN Kendari employees. The results of this research implicates the leadership of IAIN Kendari if they want to increase employee productivity in the form of targets achieved, accuracy of completing work, quality of work, and efficiency of resource utilization by employees can is done by the work of working stress at the employee's level of individuals, groups, organizations, and organizations.
\end{abstract}

Keywords: Stress, Productivity, Islamic Collage 


\section{Pendahuluan}

Pegawai sebagai salah satu unsur penunjang dari suatu perguruan tinggi, menjadi sangat penting peranannya karena berkewajiban untuk dapat melaksanakan penyelenggaraan aktivitas akademik secara tertib, tepat waktu dan lancar. Adapun tugas utama ini memberikan pelayanan administrasi akademik baik kepada para mahasiswa, dosen dan pengguna lainnya yang membutuhkan layanan bidang administrasi akademik.

Dalam upaya meningkatkan kualitas layanan pendidikan pada perguruan tinggi, maka pegawai akademik dituntut untuk mampu meningkatkan produktivitasnya melalui peningkatan layanan yang diberikan kepada para pengguna (user), sejalan dengan tuntutan perkembangan perguruan tinggi pada umumnya, dan pengembangan ilmu pengetahuan yang demikian cepat dewasa ini.Hal tersebut dikarenakan pegawai merupakan sumber daya yang sangat penting, variatif, dan terkadang menjadi masalah yang harus digunakan oleh organisasi mulai dari tingkat yang tinggi sampai tingkat yang rendah, mulai dari jumlah sedikit sampai dalam jumlah besar.

Berdasarkan begitu pentingnya peran pegawai pada perguruan tinggi di atas memberikan deskripsi yang jelas bahwa kinerja atau produktivitas pegawai hendaklah menjadi perhatian setiap lembaga perguruan tinggi, termasuk di Institut Agama Islam Negeri (IAIN) Kendari. Sebagai satu-satunya perguruan tinggi agama Islam negeri yang ada di provinsi Sulawesi Tenggara, pegawai IAIN Kendari dituntut untuk senantiasa meningkatkan produktivitasnya. Apalagi sejak peralihan status Kampus dari Sekolah Tinggi Agama Islam (STAIN) menjadi Institut Agama Islam Negeri (IAIN) pada tahun 2015 yang didasarkan pada Peraturan Pemerintah Nomor 145 tahun 2014 tentang Perubahan STAIN Kendari menjadi IAIN Kendari serta Peraturan Menteri Agama Nomor 09 Tahun 2015 tentang Organisasi dan Tata Kerja IAIN Kendari.

Berdasarkan penelusuran awal yang dilakukan, peneliti menemukan beberapa fakta terkait produktivitas dan stres kerja pegawai IAIN Kendari. Salah satunya adalah dengan peralihan status dari STAIN Sultan Qaimuddin menjadi IAIN Kendari sejak tahun 2015 menuntut adanya produktivitas kerja yang tinggi dari pegawai. Seperti penuturan salah seorang pegawai IAIN Kendari yang mengatakan bahwa sejak alih status institusi, berbagai tuntutan pekerjaan pun semakin kompleks baik dari sistem kerja yang dulunya 
berbasis jurusan kini berkembang menjadi berbasis fakultas yang tentunya beserta dengan otonomi setiap fakultas. Adanya otonomi ini tentu perlu adaptasi kerja yang baru yang menuntut adanya produktivitas yang tinggi. Hal tersebut tentu saja dapat menimbulkan stres kerja bagi pegawai IAIN Kendari. Stres kerja biasanya muncul ketika beban kerja berlebih. Misalnya, pada akhir tahun sehingga terkadang kerja lembur menjadi suatu keniscyaan. Keadaan stress kerja ini terkadang pula menimbulkan munculnya gangguan komunikasi dikarenakan keadaan psikologis akibat beban kerja yang berlebih mengurang kejiwaan pegawai sebagai penerima pesan maupun penerima pesan dalam proses komunikasi sehingga terkadang menimbulkan kesalahpahaman antar pegawai. Misalnya, suatu pekerjaan yang seharusnya dikerjakan secara tim namun harus diselesaikan oleh hanya salah satu pegawai dikarenakan masingmasing anggota tim juga memiliki pekerjaan rutinitas yang harus segera diselesaikan. Oleh karena itu, untuk mengurangi dampak negatif dari stress kerja maka sebagian pegawai berinisiatif untuk melakukan kegiatan memancing di akhir pekan bersama pimpinan dengan harapan aktivitas olahraga sekaligus refreshing ini bisa membantu dalam menyegarkan pikiran.

Permasalahan tuntutan peningkatan produktivitas ini tentu saja membutuhkan perhatian yang lebih serius dari seluruh unsur yang terkait pada lembaga perguruan tinggi untuk segara menelusuri dan menganalisis berbagai hal atau variabel yang terkait dengan peningkatan produktivitas pegawai. Salah satu variabel yang dapat diperhatikan dalam hubungannya dengan produktivitas kerja pegawai yang didasarkan pada beban kerja yang tinggi adalah stress kerja. Hal tersebut dikarenakan stres merupakan keadaan atau kejadian yang di alami seseorang yang membuat dirinya merasa tidak nyaman ataubahkan merasa tertekan. Stres kerja juga sering diartikan sebagai suatu pengalaman subyektif seseorang yang diakibatkan oleh adanya kesenjangan antara kenyataan yang terjadi tidak sesuai dengan harapannya. Kondisi ini menyebabkan timbulnya perasaan marah, cemas dan frustrasi.

Berbagai efek negatif yang muncul akibat kondisi pegawai yang sedang stres tentu sangat tidak baik bagi pegawai yang sedang dituntut untuk meningkatkan produktivitas kerjanya. Bahkan bukan produktivitas yang tinggi yang terjadi melainkan bisa jadi produktivitas pegawai bisa semakin menurun. Seperti teori yang 
mengemukakan bahwa stres kerja sebagai masalah yang utama dari suatu lembaga dalam meningkatkan tanggung jawab kerja para pegawainya. Stres kerja yang berlebihan bisa berpengaruh pada kesehatan mereka, moral, produktivitas, efisiensi organisasi, absensi, biaya pengobatan medis, dan profit individu maupun lembaga(Lussier, R. N., \& Hendon, J.R., 2017).

Penelitian terkait pengaruh stress kerja terhadap produktivitas selama ini hanya pada sektor industri atau perusahaan berbasis profit. Misalnya, peneltian yang dilakukan oleh Hoboubi,et al.pada Iranian Petrochemical Industry(Hoboubi, N., Choobineh, A., Kamari Ghanavati, F., Keshavarzi, S., \& Akbar Hosseini, A., 2017),Naqvi,et al.,yang meneliti job stress and employees' productivity pada sektor kesehatan publik (Naqvi, S., Khan, M., Kant, A., \& Khan, S.,2013), Adaramola yang meneliti tentang job stress and productivity increase(Adaramola, S. S.,2012), serta George \& Dimitriosyang meneliti pengaruh stress kerja dan kepuasan terhadap produktivitas pada sektor swasta dan publik (George \& Dimitrios, 2010). Adapun penelitian stress kerja pada pendidikan tinggi hanya meneliti tentang aspek yang mempengaruhi stress kerja. Misalnya, penelitian yang dilakukan oleh Tytherleigh,et al.,yang meneliti tentang occupational stress in UK higher education institutions. Penelitian ini berhasil menemukan bahwa sumber yang paling signifikan dari stres bagi semua staf pendidikan tinggi adalah ketidakamanan pekerjaan (job insecurity)(Tytherleigh, M. Y., Webb, C., Cooper, C. L., \& Ricketts, C.,2005).

Berdasarkan uraian di atas menunjukkan bahwa belum ada penelitian terkait pengaruh stress kerja terhadap produktivitas pada sektor pendidikan tinggi sehingga penulis tertarik untuk meneliti secara kuantitatif pengaruh stres kerja terhadap produktivitas pada sektor pendidikan tinggi, yakni pegawai Institut Agama Islam Negeri (IAIN) Kendari.

\section{Metode}

Penelitian ini menggunakan pendekatan kuantitatif melalui penelitian sebab akibat. Populasi penelitian ini adalah seluruh pegawai PNS IAIN Kendari yang berjumlah 123 orang yang terdiri dari pegawai dan dosen yang memiliki tugas tambahan administrasi.. Teknik sampel yang digunakan adalah acak sederhana (simple random 
sampling) dengan tingkat kesalahan (presisi) 5\%. Dari hasil perhitungan diperoleh jumlah sampel sebanyak 94 orang.

\section{Hasil Penelitian}

Hasil penelitian tentang stres kerja dan produktivitas kerja pegawai IAIN Kendari untuk masing-masing variabel secara berturutturut disajikan sebagai berikut:

\section{Deskripsi Data}

a. Stres Kerja Pegawai IAIN Kendari

Hasil penelitian tentang stress kerja pegawai IAIN Kendari yang diperoleh dari 94 responden yang ditabulasikan dan diperoleh skor dengan hasil sebagai berikut:

\begin{tabular}{|l|r|}
\hline Mean & 75.5000 \\
\hline Median & 75.0000 \\
\hline Std. Deviation & 4.87422 \\
\hline Variance & 23.758 \\
\hline Minimum & 65.00 \\
\hline Maximum & 87.00 \\
\hline Sum & 7097.00 \\
\hline
\end{tabular}

Hasil penelitian pada tabel di atas menunjukkan bahwa skor perolehan nilai hasil angket stres kerja pegawai IAIN Kendari diperoleh rata-rata sebesar 75,5 , skor minimum 65 , skor maksimum 87, dan standar deviasi 4,87422. Diketahui pula bahwa mean sebesar 75.5 dan nilai minimum sebesar 65. Hal ini mengindikasikan stres kerja pegawai IAIN Kendari relatif tinggi.

b. Produktivitas Kerja Pegawai IAIN Kendari

Hasil penelitian tentang produktivitas kerja pegawai IAIN Kendari yang diperoleh dari 94 responden yang ditabulasikan dan diperoleh skor sebagai berikut:

\begin{tabular}{|l|r|}
\hline Mean & 101.7234 \\
\hline Median & 102.0000 \\
\hline Std. Deviation & 11.80797 \\
\hline Variance & 139.428 \\
\hline Minimum & 68.00 \\
\hline Maximum & 123.00 \\
\hline Sum & 9562.00 \\
\hline
\end{tabular}

Hasil penelitian pada tabel 4.3 di atas menunjukkan bahwa skor perolehan nilai hasil angket produktivitas kerja pegawai IAIN 
Kendari diperoleh skor rata-rata sebesar 101.7234, skor minimum 68, skor maksimum 123, dan standar deviasi 11.80797. Diketahui pula bahwa mean sebesar 101,7 dan nilai minimum sebesar 68 . Hal ini mengindikasikan prduktivitas kerja pegawai IAIN Kendari relatif tinggi.

\section{Uji Prasyarat Analisis Data}

Pengujian terhadap asumsi-asumsi regresi sebagai persyaratan untuk melakukan pengujian hipotesis dengan langkah-langkah dan hasil pengujian sebagai berikut:

a. Uji Normalitas Data

Dalam penelitian ini digunakan uji one Sampel Kolmogorov-Smirnov dengan taraf signifikansi 0,05. Adapun hasil uji normalitas data stres kerja pegawai IAIN Kendari, yang ringkasan hasil pengujiannya turut disajikan pada tabel di bawah:

\begin{tabular}{|ll|r|}
\hline & & \multicolumn{1}{|c|}{$\mathrm{X}_{1}$} \\
\hline $\mathrm{N}$ & Mean & 94 \\
Normal Parameters $^{\mathrm{a}}{ }^{\mathrm{b}} \mathrm{b}$ & Std. & 75.5000 \\
& Deviation & 4.87422 \\
Most Extreme & Absolute & .126 \\
Differences & Positive & .126 \\
Kolmogorov-Smirnov Z & Negative & -.098 \\
Asymp. Sig. (2-tailed) & & 1.221 \\
\hline
\end{tabular}

Pada hasil output SPSS 20 yang terdapat pada tabel di atas, menunjukkan nilai signifikansi untuk variabel independen yang diuji lebih besar dari alpha atau $\alpha=0,05$, yaitu stres kerja dengan nilai probabilitas atau Sig. 0,101 maka Ho dterima (sampel berasal dari populasi yang berdistribusi normal). Hal ini berarti bahwa variabel independen yang digunakan dalam pengujian Kolmogorov-Smirnov mempunyai sebaran yang normal. Dengan demikian, dapat dilakukan pengujian lebih lanjut karena asumsi kenormalan data telah terpenuhi.

Selanjutnya, hasil uji normalitas data variabel produktivitas kerja melalui uji Kolmogorov-Smirnov, dapat dilihat pada tabel berikut:

\begin{tabular}{|l|r|}
$\mathrm{N}$ & 94 \\
\hline
\end{tabular} 


\begin{tabular}{|ll|r|} 
& Mean & 101.7234 \\
Normal Parameters & Std. & 11.80797 \\
& Deviation & .089 \\
Most Extreme & Absolute & .050 \\
Differences & Positive & -.089 \\
\multicolumn{2}{|c|}{ Negative } & .865 \\
Kolmogorov-Smirnov Z & & $\mathbf{. 4 4 2}$ \\
\hline Asymp. Sig. (2-tailed)
\end{tabular}

Pada hasil output SPSS 20 yang terdapat pada tabel di atas, menunjukkan nilai signifikansi untuk variabel independen yang diuji lebih besar dari alpha atau $\alpha=0,05$, yaitu produktivitas kerja dengan nilai probabilitas atau Sig. 0,442 maka Ho dterima (sampel berasal dari populasi yang berdistribusi normal). Hal ini berarti bahwa variabel dependen yang digunakan dalam pengujian Kolmogorov-Smirnov mempunyai sebaran yang normal. Dengan demikian, dapat dilakukan pengujian lebih lanjut karena asumsi kenormalan data telah terpenuhi.

b. Uji Linearitas Data

Hasil pengujian test for linearityuntuk variabel stres kerja dengan dengan produktivitas kerja sebagai berikut:

Anova Table

\begin{tabular}{|c|c|c|c|c|c|c|c|}
\hline & & & $\begin{array}{l}\text { Sum of } \\
\text { Squares }\end{array}$ & $\overline{D f}$ & $\begin{array}{l}\text { Mean } \\
\text { Square }\end{array}$ & $\bar{F}$ & Sig. \\
\hline & & (Combined) & 5527.58 & 19 & 290926 & 2894 & 001 \\
\hline & & & $\begin{array}{r}5 \\
277680\end{array}$ & & & & \\
\hline & Between & Linearity & 2776.88 & 1 & 2776.88 & 27.62 & .000 \\
\hline & Groups & Dow & & & & & \\
\hline $\mathrm{Y}^{*}$ & & $\begin{array}{l}\text { Deviation } \\
\text { from }\end{array}$ & 2750.70 & 10 & 150017 & $1=20$ & 107 \\
\hline$X_{1}$ & & Linearity & & 18 & 152.817 & 1.520 & .107 \\
\hline & Withir & & 7439.22 & 74 & 100.530 & & \\
\hline & Total & & $\begin{array}{r}12966.8 \\
09\end{array}$ & 93 & & & \\
\hline
\end{tabular}

Berdasarkan tabel di atas, maka diketahui bahwa nilai signifikansi dari deviation from linierity pada variabel bebas (stress kerja) dengan variabel terikat (produktivitas kerja) adalah 
0,107 . Dengan demikian, maka dapat dinyatakan bahwa nilai signifikansi dari variabel yang diteliti adalah lebih besar dari $\alpha=$ 0,05, maka dapat disimpulkan bahwa garis regresi variabel tersebut berbentuk linear sehingga bisa digunakan untuk memprediksi besarnya variabel produktivitas kerja pegawai IAIN Kendari.

\section{Pengujian Hipotesis Penelitian}

Pengujian hipotesis dalam penelitian ini adalah pengaruh stres kerja terhadap produktivitas kerja pegawai IAIN Kendari. Pada pengujian hipotesis $\left(\mathrm{H}_{0}\right)$, menyatakan bahwa tidak terdapat pengaruh langsung stres kerja terhadap produktivitas kerja diuji dengan analisis regresi linear sederhana, yang ringkasan hasil pengujian hipotesis dapat dilihat pada tabel di bawah ini:

\begin{tabular}{|c|c|c|c|c|c|}
\hline \multirow[t]{2}{*}{ Model } & \multicolumn{2}{|c|}{$\begin{array}{l}\text { Unstandardized } \\
\text { Coefficients }\end{array}$} & $\begin{array}{c}\text { Standardized } \\
\text { Coefficients }\end{array}$ & \multirow[t]{2}{*}{$\mathrm{T}$} & \multirow[t]{2}{*}{ Sig. } \\
\hline & $\mathrm{B}$ & Std. Error & Beta & & \\
\hline \begin{tabular}{ll} 
& \multicolumn{2}{c}{ Constan } \\
$1 \mathrm{t}^{-}$
\end{tabular} & $\begin{array}{r}167.94 \\
5\end{array}$ & 15.605 & & & \\
\hline$X^{1}$ & -.932 & .206 & -.426 & -4.520 & .000 \\
\hline
\end{tabular}

Berdasarkan tabel atas, diperoleh nilai koefisien arah regresi $b$ $=-0,426$ sedangkan harga konstanta $\mathrm{a}=167,945$ sehingga diperoleh persamaan regresi $\mathrm{Y}=167.945+(-0,426) \mathrm{X}_{1}$. Model persaman regresi tersebut menjelaskan bahwa untuk apabila stres kerja mengalami peningkatan atau penurunan satu poin, maka akan diikuti kenaikan atau penurunan skor produktivitas kerja sebesar 0,426 pada konstanta 167,945 .

Selanjutnya untuk melihat signifikansi regresi linear variabel stres kerja terhadap produktivitas kerja pegawai IAIN Kendari, disajikan pada tabel berikut:

\begin{tabular}{|c|c|c|c|c|c|}
\hline \multicolumn{6}{|c|}{ Anova $^{a}$} \\
\hline Model & $\begin{array}{c}\text { Sum of } \\
\text { Squares }\end{array}$ & $\overline{\mathrm{df}}$ & $\begin{array}{c}\text { Mean } \\
\text { Square }\end{array}$ & $\bar{F}$ & Sig. \\
\hline Regression & 1920.616 & 1 & 1920.616 & 20.43 & $.000^{b}$ \\
\hline 1 Residual & 8648.619 & 92 & 94.007 & & \\
\hline Total & 10569.234 & 93 & & & \\
\hline
\end{tabular}


Berdasarkan table di atas diperoleh nilai Sig $=0,000<\alpha=$ 0,05, maka dapat disimpulkan bahwa regresi linear stres kerja terhadap produktivitas pegawai IAIN Kendari adalah signifikan. Selanjutnya, berdasarkan hasil analisis jalur, nilai koefisien jalur pengaruh langsung stres kerja terhadap produktivitas kerja pegawai IAIN Kendari dapat dilihat pada nilai koefisien standardized (koefisien beta) pada tabel coefficient diperoleh $-0,426$ dan nilai sig. $=$ 0,001. Nilai sig. tersebut lebih kecil dari nilai $\alpha=0,05$ sehingga $\mathrm{H}_{0}$ ditolak, artinya stres kerja berpengaruh negatif secara signifikan terhadap produktivitas kerja pegawai IAIN Kendari.

Selanjutnya, untuk mengetahui koefisien determinasi atau besarnya kontribusi antara variabel stres kerja terhadap produktivitas kerja pegawai IAIN Kendari, maka dapat dijelaskan berdasarkan pada tabel koefisien regresi sebagai berikut:

\begin{tabular}{|l|r|r|r|r|}
\hline Model & \multicolumn{1}{|c|}{$\mathrm{R}$} & $\mathrm{R}$ Square & \multicolumn{1}{c|}{$\begin{array}{c}\text { Adjusted R } \\
\text { Square }\end{array}$} & $\begin{array}{r}\text { Std. Error of } \\
\text { the Estimate }\end{array}$ \\
\hline 1 & $.426^{\mathrm{a}}$ & .182 & .173 & 9.696 \\
\hline
\end{tabular}

Berdasarkan tabel di atas, maka koefisien determinasi $\left(\mathrm{R}^{2}\right)$ adalah sebesar 0,182 yang berarti stres kerja terhadap produktivtas kerja pegawai IAIN Kendari sebesar 18,2\%.

\section{Pembahasan}

Dari hasil pengujian hipotesis diketahui dengan jelas bahwa terdapat pengaruh negatif stres kerja terhadap produktivitas pegawai IAIN Kendari dengan nilai koefisien determinasi -0,182 atau memiliki pengaruh sebesar $18,2 \%$. Hal ini memberikan makna bahwa stres kerja akan berpengaruh langsung secara negatif terhadap produktivitas kerja pegawai IAIN Kendari. bahwa:

Hasil penelitian ini senada dengan teori yang mengatakan

As you might imagine, stressful daily events at work (a nasty email, an impending deadline, the loss of big sale, a reprimand from the boss) negatively affect moods. The effects of stress also build over time. As the authors of one study note, "a constant diet of even low-level stressful events has the potential to cause workers to experience gradually increasing levels of 
strain over time(Stephen P. Robbins \& Mary Coulter, 2012). (Stres yang mungkin kita bayangkan, seperti yang terjadi di tempat kerja contohnya e-mail yang tidak pantas, dikejar deadline, mengalami kerugian yang besar, mendapat teguran dari bos dapat memberi dampak yang negatif sehingga dapat merubah suasana hati. Dampak lain dari stres juga membuat adanya penundaan dalam menyelesaikan suatu pekerjaan, yang secara langsung membuat terjadinya kelebihan jam kerja. Seorang penulis dalam bukunya pernah meneliti bahwa stres dalam tingkat rendah juga akan membuat seorang pekerja akan mengalami peningkatan ketegangan seiring berjalannya waktu).

Greenberg dan Baronjuga mengungkapkan bahwa saat ini jelas kelihatan stres memberikan pengaruh negatif terhadap kinerja tugas para pekerja. "Stress exerts mainly negative effects on task performance as the most current evidence available suggests that"(Greenberg dan Baron,2008).Stres kerja dapat memberikan pengaruh yang negatif terhadap pekerja yang menyebabkan mereka tidak memiliki kepuasan dalam bekerja serta penurunan kinerja, komitmen mereka terhadap organisasi dan akan berdampak juga terhadap semangat pada diri para pekerja tersebut. Hal ini akan menyebabkan penurunan tingkat produktivitas mereka dalam bekerja.

Teori lain yang menghubungkan pengaruh stres terhadap produkivitas diungkapkan oleh Lussier dan Hendonbahwa:

Too much stress affects personal health, morale, productivity, organizational efficiency, absenteeism, medical costs, and profitability. So, Stress is major problem as corporate downsizing requires employees to increase their job responsibilities(Lussier, \& Hendon,2017).Stres sebagai masalah utama dari sebuah perusahaan dalam meningkatkan tanggung jawab kerja para pegawainya. Stres yang berlebihan bisa berpengaruh pada kesehatan mereka, moral, produktivitas, efisiensi organisasi, absensi, biaya pengobatan medis, dan profit perusahaan.

Teori yang hampir senada dengan teori tersebut, seperti yang dikemukakan olehSnell, S., \& Bohlander, G.,:

Professional human resources are aware of the negative effects of workplace stress on health performance and employee employment. For example, the job stress places both women and men are at risk for cardiovascular and depressive 
issues and increase the vulnerability of employees to infectious diseases. All of this contributes to higher health costs and lower productivity, job satisfaction, and retention(Snell, S., \& Bohlander, G.,2010).

Dari berbagai uraian di atas menunjukkan bahwa pegawai yang memiliki stres kerja yang tinggi akan mengalami penurunan produktivitas kerja. Kreitner, R., \& Kinicki, A., mendefinisikan stres sebagai:

Adaptive responses, mediated by individual characteristics and/or psychological processes, are the consequence of external actions, situations, or events that place-specific physical and/or psychological demands on a person(Kreitner, R., \& Kinicki, A., 2009). Stres merupakan sebuah respon adaptif dari setiap individu yang dipengaruhi oleh karakter dari setiap pribadi atau proses psikologi yang merupakan kosekuensi dari setiap tindakan atau situasi, keadaan dari luar sehingga menyebabkan adanya tuntutan psikologis maupun fisik yang khusus pada seseorang. Respon dan tanggapan seseorang menurut Kreitner dan Kinicki dalam hal ini memiliki artian bahwa tanggapan terhadap stres bisa berlainan sesuai dengan kepribadian dari masing-masing individu.

Ivancevich dan Kenopaske mendefinisikan "stress is a common experience that is part of everyone's life"(Ivancevich M, J., \& Kenopaske, R.,2008). Stres merupakan suatu pengalaman yang umum terjadi pada setiap orang. Dan selanjutnya mereka mengemukakan bahwa stres sebagai reaksi yang dialami oleh seseorang baik secara fisik, psikis maupun mental terhadap rangsangan dari lingkungan sekitarnya.

Definisi serupa juga disampaikan oleh Hughes, "stress as the process by which we perceive and respond to situations that challenge or threaten us"(Hughes, R. L., Ginnett, R. C., \& Curphy, G. J.,2009). Stres merupakan sebuah proses di mana dan bagaimana kita menanggapi situasi yang menantang atau mengancam kita. Sehingga tanggapan terhadap stres ini pada setiap individu memiliki pengaruh yang negatif. Dan tanggapan atau respon ini dapat memberikan pengaruh terhadap diri kita baik secara psikis seperti perubahan tingkat emosional, maupun fisik seperti menyebabkan peningkatan detak jantung, perubahan tekanan darah, dan tingkat kolesterol. "These responses usually include increased levels of emotional 
arousal and changes in physiological symptoms, such as increases in perspiration and heart rates, cholesterol levels, or blood pressure"(Hughes et al., 2009).

Pendapat lain tentang stres dikemukakan oleh Colquitt, "stress is defined as a psychological response to demands that possess certain stakes and that tax or exceed a person's or resources"(Colquitt, J. A., LePine, J., \& J.Wesson, M.,2011). Definisi ini memberikan pengertian bahwa stres sebagai respon psikologis terhadap suatu tuntutan tertentu serta memiliki beban yang melampaui kemampuan seseorang atau sumber daya tersebut.

Ketika seseorang dihadapkan pada situasi yang mengancam seperti munculnya konflik yang ekstrim maka akan mengalami suatu rangsangan berupa fisiologis dan emosional, hal inilah yang dinamakan stres. "When a person is faced with a situation that poses a threat (such as when an extreme conflict arises), the form of physiological and emotional arousal that he or she experiences is called stress(Vecchio, 2006).

John W. Newstrom \& Davismendefinisikan stres sebagai istilah umum yang dipakai untuk menggambarkan orang yang mengalami tekanan dalam hidupnya(John W. Newstrom, \& Davis, K.,2002). Lebih lanjut dikatakan pula bahwa stres juga banyak terjadi hampir di setiap bidang kegiatan dalam dunia kerja. Daft dalam bukunya mendefinisikan stres sebagai berikut:

Stress is an individual's physiological and emotional response to external stimuli that puts physical or psychological demands on individuals and creates uncertainty and lack of personal control when important results are at stake(Daft, R. L.,2008).

Stres adalah suatu reaksi fisik maupun emosional terhadap rangsangan atau stimulus yang timbul dari luar dirinya baik itu secara fisilogis maupun psikologis seseorang. Stres kerja secara alami diartikan sebagai suatu rangsangan, perasaan gelisah dan tekanan secara fisik yang terjadi pada seseorang dimana hal tersebut menimbulkan suatu tekanan pada orang tersebut yang melampaui kemampuan individu tersebut untuk mengatasinya, "stress is the excitement, feeling of anxiety, and/or physical tension that occurs when the demands placed on an individual are thought to exceed the person's ability to cope"(Hellriegel \& Slocum, 2011).

Selain itu, perlu juga dipahami bahwa tuntutan-tuntutan yang menyebabkan orang mengalami stres dinamakan stressor. Sedangkan 
konsekuensi-konsekuensi negatif yang terjadi ketika tuntutan itu melampaui kapasitas atau sumberdaya seseorang dinamakan strains(Colquitt et al., 2011). Definisi stres kerja ini menunjukkan bahwa stres sebenarnya tergantung pada hakikat tuntutan dan orang yang yang menghadapinya. Setiap orang berbeda-beda dalam hal bagaimana mereka mengevaluasi stressor dan bagaimana cara mereka menanganinya. Sebagai akibatnya, orang yang berbeda akan mengalami tingkatan stres yang berbeda, bahkan sekalipun mereka dihadapkan pada situasi yang persis sama.

Adapun produktivitas kerja berbicara tentang suatu ukuran lembaga dalam mencapai tujuannya. Elemen yang paling penting dan menentukan yaitu sumber daya manusia di dalam organisasi tersebut, serta harus diakui dan diterima oleh manajemen. Produktivitas kerja tidak hanya membicarakan ilmu yang terdapat dalam kajian ilmu manajemen, melainkan juga mengandung arti yang sangat dalam dan berorientasi pada sikap yang didasarkan pada kemauan yang kuat dan secara kontinu berusaha mengarah pada proses pencapaian suatu tujuan yang baik dan diinginkan.

Robbins dan Judge mendefinisikan produktivitas sebagai, "an organization is productive if it achieves its goals by transforming inputs into outputs at the lowest cost. Thus productivity requires both effectiveness and efficiency(Robbins, S. P., \& Judge, T. A.,2000). Suatu organisasi dikatakan produktif, jika dalam pencapaian tujuan organisasinya dapat mengubah input menjadi output dengan biaya terendah, dengan kata lain produktivitas membutuhkan efektifitas dan efisiensi.

Konsep yang sama tentang produktivitas seperti yang dikemukakan Griffin bahwa produktivitas dalam pengertian umum merupakan ukuran efisiensi ekonomis yang merangkum biaya yang relatif dari output dibandingkan dengan nilai input yang diperlukan untuk menghasilkan output tersebut. "In a general sense, productivity is an economic measure of efficiency that summarizes the value of outputs relative to the value of the inputs used to create them"(Griffin, 2002).

Produktivitas memiliki level-level tertentu, artinya bagaimana unit-unit analisis menentukan dalam menghitung atau mendefinisikan produktivitas. Contohnya, produktivitas agregat adalah produktivitas total yang dicapai oleh sebuah negara. Produktivitas industri adalah produktivitas total yang dicapai oleh sebuah perusahaan tertentu. 
Produktivitas unit dan indvidu berbicara tentang produktivitas yang diraih oleh sebuah unit atau departemen dalam organisasi dan oleh seorang pekerja(Griffin, 2002).

Sejalan dengan hal tersebut di atas, Robbins dan Mary Coultermengatakan bahwa:

Productivity is the number of goods or services produced divided by the inputs needed to produce the output. Individual organizations and work units want to be productive. They want to produce the goods and services that most use the fewest inputs. The Output is measured by the sales revenue an organization receives when goods are sold (the sale price multiplied by the amount sold). Inputs are measured with the cost of acquisition and transformation of resources into the output(Stephen P. Robbins, \& Mary Coulter, 2012).Produktivitas merupakan jumlah barang atau jasa yang dihasilkan dibagi dengan input yang dibutuhkan untuk menghasilkan output yang diinginkan. Dalam memproduksi barang dan jasa tersebut setiap organisasi atau individu dalam organisasi itu ingin menghasilkan suatu barang ataupun jasa dengan menggunakan masukan atau input yang serendahrendahnya.

Pendapat tersebut juga menjelaskan bahwa dalam sebuah organisasi itu selalu diusahakan untuk menekan input dan mengoptimalkan output. Sehingga biaya operasional harus menjadi pertimbangan dalam pengelolaan barang dan jasa, harga jual dikali dengan jumlah barang yang dijual kemudian dibagi dengan biaya operasional, maka dusahakan nilai jual jauh lebih tinggi dari biaya operasional, sehingga hal ini yang dimasudkan dengan produkitivitas yang tinggi.

Secara teknis produktivitas menggambarkan sebagai perbandingan rasio dari keluaran (output) dengan masukan (input). Seperti yang kemukakan oleh Newstrom, "productivity, at its simplest, is a ratio that compares units of outputs with units of inputs, often against a predetemined standard"(John W. Newstrom, \& Davis, K.,2002). Dalam pengertian yang sederhana, produktivitas adalah membandingkan unit output dengan unit input, terhadap standar unit organisasi.

Hal ini juga sejalan dengan yang dikemukakan oleh Ivancevich, et.al., bahwa: 
Productivity refelects the relationship between inputs (e.g., hours of work, effort, use of equipment) and output (e.g., personal computers produced, customer complaints handled, trucks loaded)(Ivancevich M, J., \& Kenopaske, R.,2008).

Produktivitas merefleksikan hubungan antara input atau masukan dengan output. Jika produktivitas naik hanya dimungkinkan oleh adanya peningkatan efisiensi (waktu kerja, usaha/upaya, bahan, tenaga) dan sistem kerja, teknik produksi dan adanya peningkatan keterampilan dari tenaga kerjanya. Hasil dari peningkatan produktivitas ini disebut keluaran output yang sesuai dengan yang telah direncanakan dan yang paling penting sesuai dengan keinginan dan harapan pelanggan, dengan kata lain produktivitas harus mampu menjawab keinginan dan kemauan para pelanggan serta bisa memuaskan pelanggan.

Berbagai hasil penelitian terdahulu menunjukkan hasil yang serupa dengan temuan hasil penelitian ini. Ekienabordalam penelitiannya menemukan bahwa terdapat dampak dari stres kerja pada komitmen pegawai. Ketika tingkat stres yang lebih tinggi tanpa adanya kepedulian para pimpinan memberikan solusi berakibat pada menurunnya produktivitas pegawai(Ekeniabor., E. E.,2016). Okeke, et. al., dalam penelitiannya juga menemukan bahwa berbagai tekanan beban kerja memiliki dampak signifikan terhadap produktivitas karyawan. Stres juga terbukti menghalangi kinerja yang efektif. Oleh karena itu, disarankan antara lain bahwa tindakan perbaikan perlu diambil oleh manajemen untuk meminimalkan efek stres pekerjaan secara permanen(Okeke, M. N., Echo, O., \& Oboreh, J. C.,2016). Begitupula penelitian lainnya menemukan hal yang sama bahwa faktor perubahan, tuntutan atau faktor tekanan, kurangnya dukungan dan partisipasi di tempat kerja oleh pimpinan/supervisor, rekan kerja, serta peran kerja yang lebih besar faktor yang paling stres. Hal ini kemudian berdampak pada menurunnya produktivitas pegawai (Mawanza, 2017).

Akhirnya, penelitian ini menegaskan secara empirik bahwa stress kerja berpengaruh secara signifikan terhadap produktivitas pegawai pada sektor pendidikan tinggi. Namun perlu penelitian lanjutan untuk mengetahui variabel lain yang dipengaruhi oleh stress kerja. Misalnya komitmen dan perilaku organizational citizenship behaviour (OCB) pegawai. 


\section{Kesimpulan dan Implikasi}

Temuan penelitian ini menegaskan bahwa stres kerja berpengaruh negatif secara signifikan terhadap produktivitas pegawai IAIN Kendari. Artinya, semakin tinggi stress kerja maka produktivitas kerja semakin menurun. Implikasinyabagi pimpinan IAIN Kendari jika ingin meningkatkan produktivitas pegawai baik berupa target yang dicapai, ketepatan menyelesaikan pekerjaan, mutu hasil pekerjaan, maupun efisiensi pemanfaatan sumber daya dapat dilakukan dengan meminimalisir stres kerja pegawai baik yang berupa stres pada yang muncul diakibatkan oleh berbagai faktor baik pada tingkat individu, kelompok, organisasi, maupun ekstraorganisasi.

\section{Daftar Pustaka}

Adaramola, S. S. (2012). Job stress and productivity increase. Work, 41(SUPPL.1), 2955-2958. https://doi.org/10.3233/WOR-20120547-2955

Colquitt, J. A., LePine, J., \& J.Wesson, M. (2011). Organizational Behavior. McGraw-Hill Compenies.

Daft, R. L. (2008). The Leadership Exprience. South-Western.

Ekeniabor., E. E. (2016). Impact Of Job Stress On Employees' Productivity And Commitment. International Journal for Research in Business, Management and Accounting, 2(5), 364366.

George, H., \& Dimitrios, B. (2010). The effect of stress and satisfaction on productivity. International Journal of Productivity and Performance Management, 59(5), 415-431. https://doi.org/10.1108/17410401011052869

Greenberg, J., \& Baron, R. A. (2008). Behavior in Organizations. Prentice Hall.

Griffin, R. W. (2002). Management. Houghton Mifflin Company.

Hellriegel, D., \& Slocum, J. W. (2011). [BOOK] Organizational Behavior.

Hoboubi, N., Choobineh, A., Kamari Ghanavati, F., Keshavarzi, S., \& Akbar Hosseini, A. (2017). The Impact of Job Stress and Job Satisfaction on Workforce Productivity in an Iranian Petrochemical Industry. Safety and Health at Work, 8(1), 67-71. https://doi.org/10.1016/j.shaw.2016.07.002

Hughes, R. L., Ginnett, R. C., \& Curphy, G. J. (2009). Leadership: Enhancing the Lessons of Experience. McGraw-Hill. 
Ivancevich M, J., \& Kenopaske, R. (2008). Human Resource Management. McGraw-Hill International.

John W. Newstrom, \& Davis, K. (2002). Organizational Behavior. McGraw-Hill.

Kreitner, R., \& Kinicki, A. (2009). Organizational Behavior. McGraw-Hill Compenies.

Lussier, \& Hendon. (2017). Human Resource Management: Functions, Applications, And Skill Development. Sage Publications.

Mawanza, W. (2017). The Effects of Stress on Employee Productivity: A Perspective of Zimbabwe's Socio-Economic Dynamics of 2016. Journal of Economics and Behavioral Studies, 9(2), 1-7. http://www.albayan.ae

Naqvi, S., Khan, M., Kant, A., \& Khan, S. (2013). Job stress and employees' productivity: case of azad Kashmir public health sector. Interdisciplinary Journal of Contemporary Research in Business, 5(3), 525-542.

Okeke, M. N., Echo, O., \& Oboreh, J. C. (2016). Effects of stress on learning. International Journal of Accounting Research (IJAR), 2(11), 1-14.

Robins, S. P., \& Judge, T. A. (2000). Essentials of organizational behavior robbins and judge. http://www.slideshare.net/turtemuulen/essentials-oforganizational-behavior-robbins-and-judge

Snell, S., \& Bohlander, G. (2010). Principles of Human Resource Management. Cengage Learning.

Stephen P. Robbins, \& Mary Coulter. (2012). Management. Pearson Prentice Hall.

Tytherleigh, M. Y., Webb, C., Cooper, C. L., \& Ricketts, C. (2005). Occupational stress in UK higher education institutions: A comparative study of all staff categories. Higher Education Research and Development, 24(1), 41-61. https://doi.org/10.1080/0729436052000318569

Vecchio, R. P. (2006). Organizational Behavior: Core Concepts. Thomson South-Western. 